\title{
Observing geoethics in mining and in ground-water development: An Indian experience
}

\author{
Shrikant Daji Limaye
}

Director, Ground Water Institute (NGO), Pune, India

\author{
Article history \\ Received February 14, 2012; accepted February 21, 2012. \\ Subject classification: \\ Mining, Groundwater, Geoethical practices, India.
}

\begin{abstract}
Two famous quotes from 'Mahatma Gandhi', the Indian philosopher, are helpful in describing the foundation of geoethics: (a) "God has provided enough resources for everyone's need but not for everyone's greed" and (b) "Before starting a development project, first think about the effects which the project would have on the poorest of the poor people in the Society". Geoethics is relatively a new branch in geosciences. It lies at the meeting point of geosciences, sociology and philosophy. Much earlier in the history of sciences such as nuclear physics, biology or chemistry, ethical principles attracted the attention of social leaders and philosophers while using laboratory research for field trials and applications on a large scale. Using the research not for atomic bombs but for atomic energy and not for chemical weapons but for chemical products and drugs was the priority of social leaders. In Italy, geoethics originated with philosophers and later on got the support from geologist. In other countries geoscientists working primarily in mining industry promoted geoethics for ensuring socially responsible behavior on the part of mining companies.
\end{abstract}

\section{Introduction}

Two famous quotations from Mahatma Gandhi, the Indian philosopher, are helpful in providing the 'Foundation' for geoethics since 1930s: "God has provided enough resources for everyone's need but not for everyone's greed", and "Before starting a development project, first think about the effects which the project would have on the poorest of the poor people in the society."

Geoethics is a relatively new branch of the geosciences. It lies at the meeting point of geosciences, sociology and philosophy. Much earlier in the history of science, such as with nuclear physics, biology or chemistry, ethical principles attracted the attention of social leaders and philosophers while using laboratory research for field trials and applications on large scales. Using the research not for atomic bombs but for atomic energy, and not for chemical weapons but for chemical products and medicines, was the priority of philosophers and social leaders.

In Italy, in late 1960's, Felice Ippolito, who was a geolo- gist and engineer with philosophical inclinations, began to reflect on the philosophical, sociological and historical aspects of the geosciences, considering the ethical value of geological knowledge, while using Nature or the natural resources to meet the needs of society [Ippolito 1968]. This can be interpreted as the beginnings of geoethics in Europe. Ippolito developed philosophical topics related to the geosciences, such as the relationships between man and Nature; between the scientific community, Nature and society; and the position of geology between exact sciences like mathematics, and natural sciences like biology. He had realized that scientific research is not necessarily associated with ethical values. However, the application of such research must ensure ethical considerations about the effects on society. His reflections on the ethical and social implications of the geological activities showed for the first time the importance of the role played by geoscientists in promoting and observing geoethical principles and values.

In other countries, geoscientists who were working primarily in the mining industry promoted geoethics to ensure socially responsible behavior on the parts of the mining companies. Since 1996, regular symposia on geoethics have been organized at the International Geological Congresses (IGC), and more frequently at the regular meetings of the Pribram Mining Conferences (Czech Republic) due to efforts of Vaclav Nemec and Lidmila Nemcova. Over the last three years, Silvia Peppoloni from the Instituto Nazionale di Geofisica e Vulcanologia (INGV), Rome, has been organizing sessions on geoethics at the biennial Geoltalia conferences, and recently she introduced a session on geoethics at the European General Union, General Assembly 2012 [European Geosciences Union General Assembly 2012].

\section{The multidisciplinary nature of geoethics}

As it is at the confluence of three faculties, as mentioned above, geoethics has been defined in various ways, depending on the background of its proponents. Philoso- 
phers prefer the 'precautionary principle', which emphasizes the necessity of putting restrictions on those engaged in the application of a new technology or a new activity on a larger scale, without evaluating the long-term effects of such an application. The sociologists consider geoethics from the point of view of the specific needs of society, if any, which can be fulfilled by the application of a new technology or a new activity on a larger scale. Geoscientists employed in any new development at field level or in the application of any new technology view geoethics as a set of decisions to be made at field level, through which the new development will be friendly to society and to the environment, while being economically viable to the developer. Geoscientists engaged in teaching or in government offices view geoethics as a way to guide such new developments through directives and regulations and also to educate society about the value of natural resources and their prudent use.

We thus have various stakeholders who are interested in the theory and practice of geoethics, including philosophers, sociologists, geoscientists, environmentalists, teachers, developers and businessmen promoting a new activity. There are also the participants in the activity, the regulators and policy makers in the government, and finally, the civil society that is likely to be affected by the new activity. Even in the absence of any such new development for resource use, geoethical activities of geoscientists would include: (a) ethical behavior of geoscientists within their own community; (b) efforts to educate civil society, and especially the younger generation, regarding prudent and eco-friendly use of natural resources; (c) pursuit of scientific research and dissemination of results which might be of interest or beneficial to civil society; (d) a role in educating the public about geohazards, like floods, landslides, earthquakes, droughts, and volcanic activity, and in promoting preparedness in society to face such hazards; (e) an active role in predicting geohazards, whenever possible, and in post-hazard remediation; and (f) contributions to the decision-making processes at various levels, and especially in mining development, ground water use and geohazards.

Regarding this last point, geoethical behavior expects geoscientists to ensure that the process of decision making is transparent and involves all of the stakeholders, and that the decisions are eco-friendly and can be implemented at the field level.

\section{Geoethics as applied to the mining industry}

For many years, mining was considered as a nonsustainable activity. This is because mining includes the physical removal of a non-renewable resource from one site for further processing and use. The resource itself is thus not sustainable. Sustainability of mining is a relatively re- cent concept, which embodies geoethical behavior towards the society close to the mining area.

The society close to mines is considered to have several types or aspects of 'capital', such as natural resources capital, educated people or human resources capital, infrastructure, employment opportunities, health services, productive farms, a clean environment, and social institutions. All these are what we can call the 'social capital', which contributes to a stable social order and community well-being [Rajaram et al. 2011]. Due to mining activities in its neighborhood, the natural resources capital is permanently lost, with possible partial loss in other aspects of capital, like a clean environment. Sustainable mining incorporates compensation for the society towards these losses by increasing several other capital assets mentioned above. During the operation of mining, various aspects of the capital of the society can be enhanced by the mine developers, like education for children, job opportunities for elders, health services at a company hospital, and the infrastructure for an electricity supply, roads and markets. These would continue during the several years or decades of the mining operation.

However, even after active mining stops, sustainability for the society can be achieved by effective rehabilitation processes. Some of the cement companies in India have taken up such rehabilitation processes by using old mine pits for creating large water storage to promote fisheries, forestry, and irrigation for agriculture. The 'self-help groups for village women' that were created during active mining continue to work as 'value addition' to agricultural produce or production of handicrafts in the rehabilitation phase. In large cement factories, active mining goes on in new sectors, while rehabilitation takes place in old, usedup sectors. Geoscientists have an important role in this rehabilitation.

One of the coastal cement factories in India used a farmer friendly approach in ground water use. The farmers in the surrounding villages were worried that the factory would pump a lot of ground water from its mining lease areas at high levels, for the construction and operation of the factory, thereby promoting sea-water intrusion into irrigation wells of the farmers located at the lower levels closer to the sea. The factory authorities declared that they would not pump any ground water from the mining area. The factory entered into an agreement with the farmers that the farmers should supply water to the factory from their wells rather than using it for irrigation and the factory would pay them in cash on a daily basis, which would be much more than what they could earn from the irrigated crops. After the factory started working at full capacity, it used hot gases in the chimney for sea water desalination for industrial use. The factory also promoted ground water recharge by using the lowest levels 
of the mine pits as ground-water recharge ponds during the monsoon rainy season. This increased the water availability in the wells of the farmers, and also checked the intrusion of saline water in the aquifer.

\section{Geoethics in ground-water use}

In India, and also in several other low-income countries, the ownership of ground water lies with the land owner. Therefore, the farmers have a strong sense of ownership of whatever ground water there is within their farms. Suppose a farmer has a good well on his farm. Then his neighbor also digs or drills a well on his own farm, not far from this good well, with the result that the yield of the good well is considerably reduced. Here, there is no court case, law suit or ethical considerations. Each farmer knows that it is perfectly legal to dig or drill a new well on their tiny farmland, irrespective of any consideration of the effects that the new well might have on the yields of existing wells in the vicinity.

In a mini-watershed of about $100 \mathrm{Ha}$, suppose a farmer has a $1 \mathrm{Ha}$ farm in which he is lucky to have a very good well, so that he can pump out large quantity of ground water and irrigate his whole farm of $1 \mathrm{Ha}$ with 'high water demand' crops, like banana or sugarcane. In the view of geoethics, the farmer's equitable right to the ground water resources of the mini-watershed is just $1 \%$, according to the area of his farm. However, just because he is lucky, how much of the share of ground water in the watershed can he rightfully pump from his well? Five percent? Ten percent? This is a very difficult question to answer at the village level. If the farmer is not ready to reduce his pumping, the geoethical behavior on his part will be to make provision for increasing the ground water recharge during the monsoon rainy season. This could be done by collecting the runoff water in a farm pond, allowing it to settle and then filtering and putting it into the good well.

Moving further from the scale of a farm to the scale of a watershed, we find that in many watersheds the pumping of ground water has increased considerably in the past 30 years, and the water table has become depleted. Increasing the recharging of the ground water has been traditionally considered as the responsibility of the government. Only recently have some of the village councils taken a lead in increasing the recharging by convincing the farmers that ethically it is their duty to recharge the aquifer because they have depleted it through excessive pumping.

Pollution of ground water by industries is another issue in which there is a need to stress the principle of 'the polluter must pay' upon the industries. However, the best practice is to prevent the pollution from occurring in the first place, rather than trying any remediation of a polluted aquifer.

\section{Conclusions}

Although it is a relatively new branch in the Faculty of Geosciences, Geoethics is gradually assuming importance because observing ethical behavior while developing geo-resources or while dealing with geohazards, has become an urgent need of the society. Geoscientists have a duty to educate society on prudent and eco-friendly use of these resources, and also to increase the preparedness of society in dealing with geohazards. The success of the session on geoethics at the GeoItalia conference in 2011 in Turin [Geoltalia 2011] was a good indication that Italian geoscientists are increasingly becoming aware of this duty, and are poised to take a leading position on the global stage. As a low-income country, some of the nongovernmental organizations and business houses in India are also taking an active interest in this field.

\section{References}

European Geosciences Union General Assembly (2012). Vienna, Austria; http:/ / www.egu2012.eu/home.html. Geoitalia (2011). VIII Italian Forum on Earth Sciences, Turin, Italy; http:/ / www.geoitalia.org/index.php?action =folder_list\&folder_id $=214$.

Ippolito, F. (1968). La natura e la storia, Milano, Vanni Scheiwiller (in Italian).

Rajaram, V., S. Dutta and K. Parameswaran (2011). Sustainable mining practices - A global perspective, AA Balkema Publishers, 370 pp.

Corresponding author: Shrikant Daji Limaye, Director, Ground Water Institute (NGO), Pune, India; e-mail: limaye@vsnl.com

C 2012 by the Istituto Nazionale di Geofisica e Vulcanologia. All rights reserved. 